Isono, K., and others. A physical study of solid precipitation from convective clouds over the sea: part III, by K. Isono, M. Komabayashi [and] T. Takahashi. Journal of the Meteorological Society of Japan, Ser. 2, Vol. 44, No. 4, I966, p. 227-33. [Measurement of electric charge of snow crystals.]

Isono, K., and others. A physical study of solid precipitation from convective clouds over the sea: part IV, by K. Isono, M. Komabayashi, T. Takahashi and T. Gonda. Journal of the Meteorological Society of Japan, Ser. 2 , Vol. 44, No. 6, r 966, p. 308-ig. [Importance of giant sea salt nuclei in formation of solid precipitation.]

KAISERgRUBER, F. Eine merkwürdige Schneeform ("Schneerollen"). Wetter und Leben, Bd. 1 7, Ht. 3-4, 1965, p. 67-68. [Description of curious toroidal form.]

MagONo, C., and KIKUCHI, K. On the positive electrification of snow crystals in the process of their melting (II). Journal of the Meteorological Society of Japan, Ser. 2, Vol. 43, No. 6, 1966, p. 331-42. [Measurement of charge on snow crystals in process of melting.]

Magono, C., and Nakamura, T. Aerodynamic studies of falling snowflakes. Fournal of the Meteorological Society of Japan, Ser. 2, Vol. 43, No. 3, 1965, p. 139-47. [Simultaneous observations of fall velocity, size and mass.]

Martinelli, M., jr. Avalanche technology and research: recent accomplishments and future prospects. Weatherwise, Vol. I9, No. 6, I966, p. 270-71. [Including current avalanche control and forecasting techniques.]

Ōura, H., and Kobayashi, D. Sekisetsu no ryūdo bumpu no motomekata ni tsuite [On the method of size frequency distribution analysis of ice particles in snow cover]. Teion-kagaku [Low Temperature Science], Ser. A, Vol. 24, I 966, p. I39-57. [Determination from microphotographs of cross-sections of snow cover. English extended summary p. 155-57.]

Pitman, D., and Zuckerman, B. Effective thermal conductivity of snow at $-88^{\circ},-27^{\circ}$, and $-5^{\circ} \mathrm{C}$. 7 ournal of Applied Physics, Vol. 38, No. 6, I967, p. 2698-99. [Measurements of conductivity of "snow" made from dendritic frost crystals with density from 0.1 to $0.6 \mathrm{~g} \mathrm{~cm}^{-3}$. Comparison with previous work and theory.]

RAкiтA, S. A. Vliyaniye rastitel'nosti na perenos i otlozheniye snega v gorakh basseyna Kolymy [Influence of vegetation on transport and deposition of snow in the mountains of the Kolyma basin]. Vestnik Moskovskogo Universiteta. Seriya 5 [Messenger of Moscow University. Series 5], God 21, [No.] 3, 1966, p. 103-07.

Roch, A., and Fraser, C. How to estimate avalanche danger. Alpine Journal, Vol. 72, No. 314, r967, p. 87-94.

Stow, C. D. The generation of electricity by blowing snow. Weather, Vol. 23, No. 9, 1967, p. 371-77. [Three types of interaction, all involving the temperature-gradient effect, are primarily responsible for the observed electrification.]

Тном, H. C. S. Distribution of maximum annual water equivalent of snow on the ground. Monthly Weather Review, Vol. 94, No. 4, r966, p. 265-71. [Study of statistical distribution.]

TushinskiY, G. K., and others. Karta lavinoopasnykh rayonov SSSR [Map of avalanche-dangerous regions in the U.S.S.R.], [by] G. K. Tushinskiy, K. V. Akif'yeva, N. A. Volodicheva, N. L. Kondakova, G. S. Konstantinova, V. I. Kravtsova, I. S. Kuz'mina, V. F. Perov, S. A. Rakita, Ye. S. Troshkina, O. A. Shleynite. Vestnik Moskovskogo Universiteta. Seriya 5 [Messenger of Moscow University. Series 5], God 22, [No.] I, 1967, p. 3-14.

Wilken, G. C. Snow accumulation in a manzanita brush field. Water Resources Research, Vol. 3, No. 2, ig67, p. 409-22. [Study of how snow accumulates in areas of Sierra Nevada, U.S.A., covered by this shrub.]

Zanin, G. V. Snezhnye melioratsii i geomorfologicheskiye protsessy [Snow irrigation and geomorphological processes]. Izvestiya Akademii Nauk SSSR. Seriya Geograficheskaya [News of the Academy of Sciences of the U.S.S.R. Geographical Series], 1966, No. 3, p. 49-51.

\title{
ERRATUM (Vol. 6, No. 45)
}

In the entry in "Glaciological literature" on p. 473, Woldstedt, P. Die interglazialen . . ., the note in square brackets should read: [The interglacial marine beaches are "raised beaches" and do not prove a former higher ocean level; it can be shown that ocean levels have not altered appreciably during the Quaternary, thus most Antarctic ice must have been formed before this.]

\section{NOTE FOR AUTHORS}

In view of the impending retirement of Dr. Gerald Seligman from his Editorship of the Journal of Glaciology, authors are requested to send their manuscripts to Dr. J. W. Glen, Department of Physics, University of Birmingham, P.O. Box $36_{3}$, Birmingham 15, England and not to Dr. Seligman. 